\title{
An Alternative Approach for Acetylation of Amine Terminated Poly- amidoamine (PAMAM) Dendrimer
}

\author{
Un enfoque alternativo para la acetilación de la amina terminal del dendrímero de \\ poliamidoamina (PAMAM)
}

\author{
Surya Prakash Gautam ${ }^{1}$ - Raj K. Keservani ${ }^{2} \cdot$ Tapsya Gautam $^{3} \cdot$ Arun K. Gupta $^{3}$ - Anil Kumar Sharma ${ }^{1}$ \\ 1. Department of Pharmaceutics, CT Institute of Pharmaceutical Sciences, Jalandhar, Punjab \\ 2. School of Pharmaceutical Sciences, Rajiv Gandhi Proudyogiki Vishwavidyalaya, Bhopal (M.P.), India. \\ 3. Smriti College of Pharmaceutical Education, 4/1, Piplya Kumar Kakad, Mayakhedi Road, Dewas Naka, Indore (MP), India.
}

\section{Artículo Original Original Article}

\section{Correspondencia} Correspondence

Raj K. Keservani

School of Pharmaceutical Sciences, Rajiv Gandhi Proudyogiki Vishwavidyalaya, Bhopal, India-462036 Mobile: +917897803904 rajksops@gmail.com

\section{Financiación}

Fundings

No funding agency for the research work.

\section{Conflicto de interés}

Competing interest

Author declares no conflict of interest.

\section{Agradecimientos}

Acknowledgements

Authors are thankful to the Mr. Adi Dev Bharti, for valuable suggestion.

Support for research facilities by CDRI, Lucknow, Scope, Indore is thankfully acknowledged.

\section{Received: 01.02.2015} Accepted: 06.04.2015

\section{c) creative} LICENSE 3.0 UNPORTED.

\section{RESUMEN}

Objetivos. Las propiedades inherentes de la poliamidoamina (PAMAM) la han convertido en el nanotransportador de elección en la era actual de la innovación. A pesar de que sufren de toxicidad hemolítica que podría ser reducido mediante la protección del grupo amino libre. En el presente trabajo se discutió el método alternativo de acetilación para los dendrímeros PAMAM.

Material y Métodos. El enlazador 1-Etill-3-(3-dimetilaminopropil) carbodiimida (EDC) se utilizó para la acetilación. El conjugado acetilado se evaluó mediante la reacción de color, mediante espectroscopia Ultravioleta visible, espectroscopia infrarroja con transformado de Fourrier, Calorimetría Diferencial de barrido y los estudios de los espectros de Resonancia magnetica nuclear..

Resultados. Los dendrímeros PAMAM se sintetizaron utilizando el método divergente y más acetilado. Cambio en los valores $\lambda \max 282,0$ a $282,5 \mathrm{~nm}$ se observó para dendrímeros acetilados. El pico característico del NH de amina primaria a 3284,16 cm-1, desapareció debido a la conversión de amina primaria a amina secundaria. Un nuevo pico de - (CO) -NH se obtuvo a 1640,28 cm-1 (medianas), que muestra la unión de grupo de superficie de ácido acético. Se observaron los cambios en el pico endotérmico de 120,56 a $110.40{ }^{\circ} \mathrm{C}$ que muestra las modificaciones superficiales de dendrímeros PAMAM. El pico de $-\mathrm{NH}_{2}$ en 2,99 ppm fue sustituido por $\left(-\mathrm{NHCOCH}_{3}\right)$ a 2,42 ppm apoya aun más la prueba de acetilación.

Conclusión. Los datos espectrales revelaron claramente que este enfoque para la acetilación da considerable cantidad de acetilación en menos tiempo de duración con la eliminación de disolvente orgánico. Este método podría ser empleado para regular la acetilación de las aminas terminales de nanovehículos. El enlazador EDC de grupos amino abre una nueva vía para la acetilación de amina terminales de proteínas / péptidos.

Palabras clave: dendrímeros, poliamidoamina (PAMAM), Etylenediamine, acetilación, vinculador, Propiedades de la superficie.

\begin{abstract}
Aim. Polyamidoamine (PAMAM) dendrimers inherent properties have made it the nanocarrier of choice in the current era of innovation. Dendrimer based products are growing and mushrooming like anything in the current time. Although it suffer from hemolytic toxicity which could be reduced by protecting free amino group.
\end{abstract}

Methods. In the present work alternate acetylated method for PAMAM dendrimers was discussed. 1-Ethyl-3-(3-dimethylaminopropyl) carbodiimide Linker was used for acetylation. The acetylated conjugate was evaluated for color reaction, Ultraviolet-visible spectroscopy, Fourier Transform infrared spectroscopy, Differential scanning calorimetric, Nuclear magnetic resonance spectra studies.

Results. The PAMAM dendrimers were synthesized using divergent approach and further acetylated. Change in $\lambda_{\max }$ values from 282.0 to $282.5 \mathrm{~nm}$ was observed for acetylated dendrimers. Characteristic peak of N-H stretch of primary amine at $3284.16 \mathrm{~cm}^{-1}$ was disappeared due to conversion of primary 
amine to secondary amine. A new peak of -(CO)-NH stretch was obtained at $1640.28 \mathrm{~cm}-1$ (medium) which shows attachment of acetic acid surface group. The changes in Endothermic peak from 120.56 to $110.40^{\circ} \mathrm{C}$ were observed which shows the PAMAM dendrimers surface modifications The peak of $-\mathrm{NH}^{2}$ at $2.99 \mathrm{ppm}$ was replaced by $(-\mathrm{NHCOCH} 3)$ at 2.42 ppm further supports the proof of acetylation.

Conclusions. The spectral data clearly revealed that this approach for acetylation gives considerable amount of acetylation in less time duration with elimination of organic solvent. This method could be employed for regular acetylation of amine terminated nanocarriers. EDC linker mediated capping of amine groups opened a new avenue for acetylation of amine terminated protein/peptides.

Keywords: Dendrimers, Polyamidoamine (PAMAM), Etylenediamine, Acetylation, Linker, Surface Properties.

\section{INTRODUCTION}

Despite of its short history of nearly three decades it has proved itself in the market. Dendrimers based products are contributing significantly and efficiently. Top leaders and Pharma giant companies are strengthening their global presence by launching dendrimer based products ${ }^{1}$. The exposed groups on outer surface are available to bind the moieties that can facilitate in drug targeting. Dendrimers claims plethora of medicinal activities and is carrier of choice in delivering the drug at the area of interest ${ }^{2-6}$. Cross linkers help to couple ligand with dendrimers. Hemolysis toxicity mainly due to free amine groups is major problem that limits their utilization in clinical applications. Research scientist across the world is actively working on this segment to solve the issue. Surface capping may contribute to make nanocarriers nontoxic, biocompatible, biodegradable. Their pharmacodynamic and pharmacokinetic attributes may be improved ${ }^{7}$. Acetylation is one more approach for capping the free amine groups of dendrimers. Dendrimer acetyl conjugates may reduce the hemolytic toxicity and cytotoxicity problems associated with unmodified dendrimers. Pioneering work in this segment was performed by Majoros et al.., 2003 with commercial success of this novel $\operatorname{method}^{8}$.

Literature survey disclosed that remarkably few methods are reported for the acetylation of PAMAM dendrimers ${ }^{9}$ Solubility enhancements of poorly soluble compounds is facilitated by acetylated conjugates ${ }^{8}$. Acetic anhydride is popularly used for acetylation of amine terminated PAMAM dendrimers. Utilization of dendrimers for drug delivery applications while reducing their cytotoxicity is the area were scientist are working actively. Plethora of strategies are used to minimize the cytotoxicity of dendrimers ${ }^{10-13}$. Neutralizing charges by amine acetylation enhances the transfection efficiency of plasmid DNA 9,14 . Quite a number of examples have appeared recently where researchers have nicely illustrated the biomedical application of surface modified dendrimers ${ }^{15,16}$. In present research work a new approach have been developed that may open new horizons for the drug delivery.

\section{MATERIALS AND METHODS}

\section{Materials}

Ethylenediamine (Merck Specialities (P) Ltd) and Methylacrylate (Loba Chem (P) Ltd., Mumbai) were used after redistillation. Glacial acetic acid was obtained from (Loba Chem (P) Ltd., Mumbai). EDC was obtained from (Loba Chem (P) Ltd., Mumbai). Rest all the chemicals were purchased from Loba Chem (P) Ltd., Mumbai. All Solvent was HPLC grade.

\section{Preparation of Acetylated 4.0G PAMAM Dendrimers}

Acetylation of PAMAM 4.0G dendrimers was done using EDC as a cross linking agent. PAMAM dendrimer (1.0 $\mathrm{gm})$ was solubilized in distilled water and cooled down to $0-5^{\circ} \mathrm{C}$. In another round bottom flask glacial acetic acid (32 equimolar) was taken and aqueous solution of EDC (32 equimolar) was added drop wise for half an hour at $0-5^{\circ} \mathrm{C}$ to with constant stirring. In this reaction mixture solution of PAMAM 4.0G dendrimer was added dropwise at $0-5^{\circ} \mathrm{C}$ for $1 \mathrm{~h}$ with constant stirring. Mixture was kept aside for $24 \mathrm{~h}$. Finally by-products were removed by dialysis. Final product was concentrated under vacuum (Scheme 1).

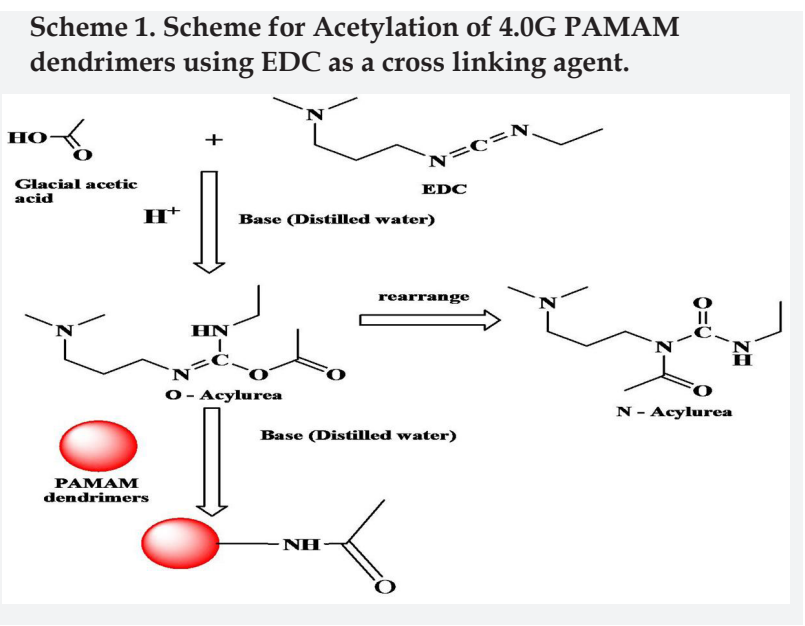

Evaluation of Acetylated 4.0G PAMAM Dendrimers

Color test

PAMAM dendrimers and acetylated derivatives were treated with aqueous solution of copper sulphate $(1 \% \mathrm{w} / \mathrm{v})^{17}$. 
Ultraviolet Spectroscopy

$0.01 \% \mathrm{w} / \mathrm{v}$ concentration of PAMAM dendrimers was scanned in the range of $200 \mathrm{~nm}$ to $500 \mathrm{~nm}$ against distilled water. The changes in $\lambda_{\max }$ values were analyzed ${ }^{18-20}$.

\section{FT-IR Spectroscopy}

The 4.0G PAMAM dendrimer and acetylated derivatives were subjected to FT-IR spectroscopy analysis ${ }^{21}$.

\section{Differential Scanning Calorimetric (DSC)}

The samples were kept in aluminum disc and set in a Perkin Elmer DSC apparatus (Uberlingen, Germany) over the range of $50-200^{\circ} \mathrm{C}$. Analysis was performed at a heating rate maintained at $20^{\circ} \mathrm{C}$ per minute in a nitrogen atmosphere. Alumina was used as a reference substance. Spectrum was recorded using TA 60W software and obtained spectra ${ }^{22}$.

\section{NMR Spectroscopy}

The dendrimers were evaluated by NMR spectroscopy. $\mathrm{D}_{2} \mathrm{O}$ was used to solublize 4.0G and acetylated dendrimers. Deuterated methanol was used as co-solvent and analyzed at $300 \mathrm{MHz}$. NMR signal were recorded for 4.0G PAMAM and acetylated analogs 23,24 .

\section{RESULTS AND DISCUSSION}

\section{Color Reaction}

The plain dendrimers gives violet color due to free $-\mathrm{NH}_{2}$ groups. The acetylated dendrimers shows less instance violate color due to decreases in free $-\mathrm{NH}_{2}$ groups on acetylation. The color reaction provides preliminary information regarding the surface modification of $4.0 \mathrm{G}$ dendrimers.

\section{Ultraviolet Spectroscopy}

Absorption maxima $\left(\lambda_{\max }\right)$ were recorded for $4.0 \mathrm{G}$ dendrimers and surface modified dendrimers. The change in $\lambda_{\max }$ values from 282.0 to $282.5 \mathrm{~nm}$ was observed for surface modified dendrimers, which indicates change in surface chemistry of PAMAM dendrimers.

\section{FT-IR Spectroscopy}

The 4.0G and acetylated derivatives were analyzed by FTIR spectroscopy analysis by FTIR 470 Plus, Jasco, Japan. The FT-IR peaks provide the proof of modification of free amino group into amide group. The characteristic peak of $4.0 \mathrm{G}$ PAMAM dendrimers were of $\mathrm{N}-\mathrm{H}$ stretch of primary amine at $3284.16 \mathrm{~cm}^{-1}, \mathrm{~N}-\mathrm{H}$ stretch of anti-symmetric substituted primary amine at $3146.67 \mathrm{~cm}^{-1}, \mathrm{C}-\mathrm{H}$ stretch at $2919.48 \mathrm{~cm}^{-1}$. IR spectra of Acetylated PAMAM dendrimer, characteristic peak of N-H stretch of primary amine at $3284.16 \mathrm{~cm}^{-1}$ was disappeared due to conversion of primary amine to secondary amine. A new peak of -(CO)-NH stretch was obtained at $1640.28 \mathrm{~cm}-1$ (medium) which shows attachment of acetic acid surface group. FT-IR spectra of 4.0G PAMAM dendrimers and Acetylated dendrimers are given in Figure 1 and Figure 2 respectively.

\section{Figure 1. FTIR Spectra of 4.0G PAMAM Dendrimers}

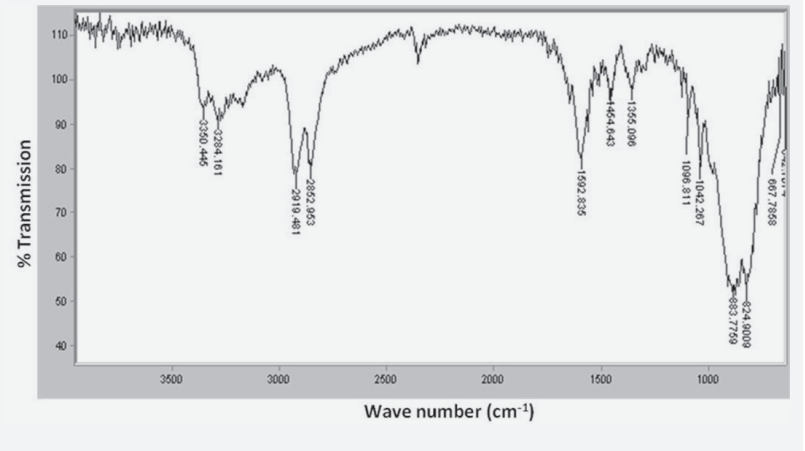

Figure 2. FTIR Spectra of Acetylated PAMAM Dendrimers

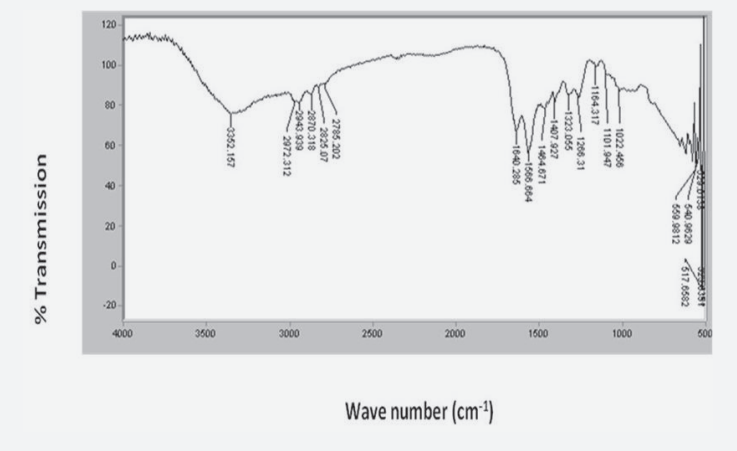

\section{Differential Scanning Calorimetric (DSC)}

The changes in Endothermic peak were analyzed. The changes in Endothermic peak from 120.56 to $110.40^{\circ} \mathrm{C}$ were observed which shows the PAMAM dendrimers surface modifications.

\section{NMR Spectroscopy}

NMR spectra further confirm the Acetylation of PAMAM dendrimers. The sample was analyzed by NMR spectroscopy by Bruker DRX-300. $\mathrm{D}_{2} \mathrm{O}$ was used to dissolve 4.0G PAMAM dendrimers and Acetylated PAMAM dendrimers and methanol as co solvent and analyzed at $300 \mathrm{MHz}$. Shifts in peaks was for terminal groups of $-\mathrm{NHCH} 2 \mathrm{CH} 2 \mathrm{NH} 2$ at $3.46 \& 2.99$ ppm. The NMR spectra and shifts of Acetylated PAMAM dendrimers provide the proof of acetylation. The peak of $-\mathrm{NH}^{2}$ at $2.99 \mathrm{ppm}$ was replaced by $(-\mathrm{NHCOCH} 3)$ at $2.42 \mathrm{ppm}$. The results obtained are given in Table 1. The NMR spectra of 4.0G and Acetylated dendrimers are given in Figure 3 and Figure 4 respectively. 


\section{CONCLUSIONS}

Acetylation done using EDC as a cross linking agent and glacial acetic acid gives a alternative way for the surface modification of PAMAM dendrimers. It proves to be a bet-

Figure 3. NMR Spectra of 4.0G PAMAM Dendrimers

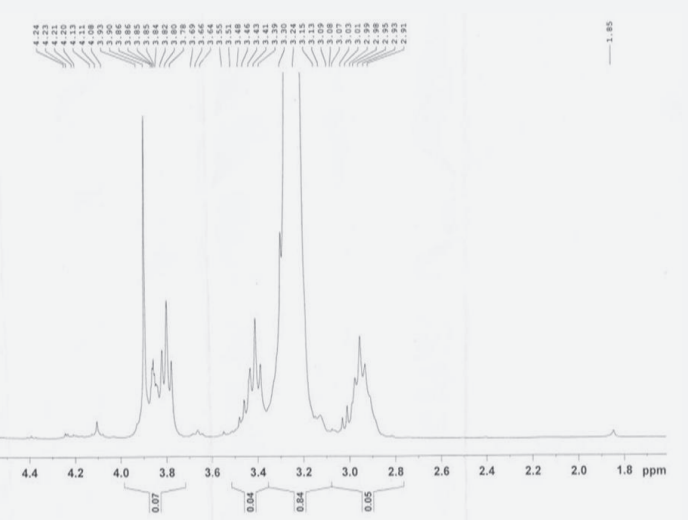

ter technique for Acetylation of dendrimers. Therefore, in the future, more attention should be paid to improving the synthesis and surface modification of novel dendritic polymers and exploring the novel possible applications.
Figure 4. NMR Spectra of Acetylated PAMAM Dendrimers

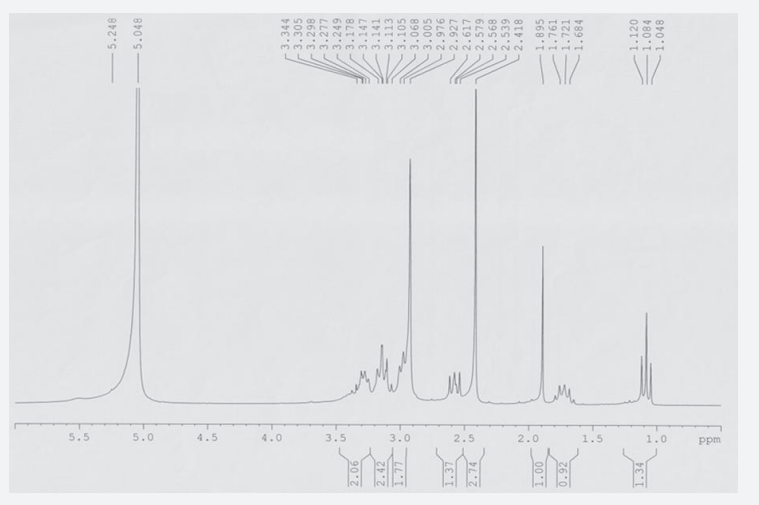

Table 1. NMR shifts and interpretation of the spectrum of 4.0G Polyamidoamine (PAMAM) and Acetylated dendrimers

\begin{tabular}{|c|c|c|c|}
\hline \multicolumn{2}{|c|}{ Interpretation } & \multirow{2}{*}{$\begin{array}{c}\text { 4.0G PAMAM } \\
\delta \text { values (ppm) } \\
2.93\end{array}$} & \multirow{2}{*}{$\begin{array}{l}\text { Acetylated } 4.0 G \\
\text { PAMAM } \\
\delta \text { values (ppm) } \\
2.93\end{array}$} \\
\hline$-\mathrm{NCH}_{2} \mathrm{CH}_{2} \mathrm{~N}-$ & $-\mathrm{NC} \underline{\mathbf{H}}_{2} \underline{\mathrm{CH}}_{2} \mathrm{~N}-$ & & \\
\hline$-\mathrm{NCH}_{2} \mathrm{CH}_{2} \mathrm{CO}-$ & $-\mathrm{NC}_{2} \mathrm{CH}_{2} \mathrm{CO}-$ & 2.98 & 2.98 \\
\hline$-\mathrm{NCH}_{2} \mathrm{CH}_{2} \mathrm{CO}-$ & $-\mathrm{NCH}_{2} \mathrm{C}_{2} \mathrm{CO}-$ & 2.91 & 2.93 \\
\hline$-\mathrm{CONHCH}_{2} \mathrm{CH}_{2} \mathrm{~N}-$ & $-\mathrm{CONHC} \underline{\mathbf{H}}_{2} \mathrm{CH}_{2} \mathrm{~N}-$ & 3.30 & 3.30 \\
\hline$-\mathrm{CONHCH}_{2} \mathrm{CH}_{2} \mathrm{~N}-$ & $-\mathrm{CONHCH}_{2} \underline{\mathrm{CH}}_{2} \mathrm{~N}-$ & 2.95 & 2.95 \\
\hline$-\mathrm{CONHCH}_{2} \mathrm{CH}_{2} \mathrm{NH}$ & $-\mathrm{CONHC} \underline{\mathrm{H}}_{2} \mathrm{CH}_{2} \mathrm{NH}_{2}-$ & 3.46 & 3.34 \\
\hline$-\mathrm{CONHCH}_{2} \mathrm{CH}_{2} \mathrm{NH}_{2}$ & $-\mathrm{CONHCH}_{2} \underline{\mathrm{C}}_{2} \mathrm{NH}_{2}^{-}$ & 2.99 & - \\
\hline$-\mathrm{NHCOCH}_{3}$ & $-\mathrm{NHCOC \textrm {H } _ { 3 }}-$ & - & 2.42 \\
\hline
\end{tabular}




\section{REFERENCES}

1. Garg T, Singh O, Saahil A, Murthy RSR. Dendrimers-A novel scaffold for drug delivery. Intl. J. Pharm. Sci. Rev. Res. 2001; 7: 211-220.

2. Konda SD, Aref M, Wang S, Brechbiel M, Wiener EC. Specific targeting of folate-dendrimer MRI contrast agents to the high affinityfolate receptor expressed in ovarian tumor xenografts. MAGMA. 2001; 12 (2-3): 104-113.

3. Namazi H, Adeli M. Dendrimers of citric acid and poly (ethylene glycol) as the new drug- delivery agents. Biomaterials. 2005; 26: 1175-1183.

4. Patri AK, Kukowska-Latallo JF, Baker JR. Targeted drug delivery with dendrimers: comparison of the release kinetics of covalently conjugated drug and non-covalent drug inclusion complex. Adv Drug Deliv Rev. 2005; 57: 220322-14.

5. Zeng F, Zimmerman SC. Dendrimers in supramolecular chemistry: From molecular recognition to self-assembly. Chem. Rev. 1997; 97 (5): 1681-1712.

6. Purohit G, Sakthivel T, Florence AT. Interaction of cationic partial dendrimers with charged and neutral liposomes. Intl. J Pharm. 2001; 214: 71-76.

7. Yellepeddi VK, Kumar A, Palakurthi S. Surface modified poly(amido)amine dendrimers as diverse nanomolecules for biomedical applications. Exp. Opin. Drug Deliv. 2009; 6 (8): 835-850.

8. Majoros IJ, Keszler B, Woehler S, Bull T, Baker JR. Acetylation of poly(amido)amine dendrimers. Macromolecules. 2003; 36: 5526-5529.

9. Kolhatkar RB, Kitchens KM, Swaan PW, Ghandehari H. Surface acetylation of poly(Amidoamine) (PAMAM) dendrimers decrease cytotoxicity while maintaining membrane permeability. Bioconjugate. Chem. 2007; 18 (6): 2054-2060.

10. Waite CL, Sparks SM, Uhrich KE, Roth CM. Acetylation of PAMAM dendrimers for cellular delivery of siRNA. BMC Biotechnology. 2009; 9: 38 doi:10.1186/1472-6750-9-38

11. Jevprasesphant R, Penny J, Jalal R, Attwood D, McKeown NB, D'Emanuele A. The influence of surface modification on the cytotoxicity of PAMAM dendrimers. Intl. J. Pharm. 2003; 252: 263-266.

12. Kim T, Seo HJ, Choi JS, Jang HS, Baek JU, Kim K, Park JS. PAMAM-PEG-PAMAM: novel triblock copolymer as a bio- compatible and efficient gene delivery carrier. Biomacromolecules. 2004; 5: 2487-2492.

13. Forrest ML, Meister G, Koerber J, Pack D. Partial acetylation of polyethylenimine enhances in vitro gene delivery. Pharm. Res. 2004; 21: 365-371.

14. Gabrielson NP, Pack DW. Acetylation of polyethylenimine enhances gene delivery via weakened polymer/DNA interactions. Biomacromolecules. 2006; 7: 2427-2435.

15. Sharma A, Gautam SP, Gupta AK. Surface modified dendrimers: Synthesis and characterization for cancer targeted drug delivery. Bioorg. Med. Chem. 2011; 19: 3341-3346.

16. Khambete H, Gautam SP, Karthikeyan C, Ramteke S, Moorthy NSHN, Trivedi P.A new approach for PEGylation of dendrimers. Bioorg. Med. Chem. Lett. 2010; 20: 4279-4281.

17. Gautam SP, Gupta AK, Sharma A, Gautam T. Synthesis and analytical characterization of ester and amine terminated PAMAM dendrimers. Global J Med. Res. Pharma, Drug Dis. Toxicol. Med. 2013; 13(3): 7-15.

18. Erk N. Application of first derivative UV-spectrophotometry and ratio derivative spectrophotometry for the simultaneous determination of candesartan cilexetil and hydrochlorothiazide. Phmz. 2003; 58(11): 796-800.

19. Ronald CH, Bauer BJ, Paul SA, Franziska G, Eric A. Templating of inorganic nanoparticles by PAMAM/PEG dendrimerstar polymers. Polymer. 2002; 43:5473-5481.

20. Lajos PB, Ganser RT, Xiangyang S. Characterization of dendrimer-gold nanocomposite materials. Mater. Res. Soc. Symp. Proc, 2005; 847 .

21. Pesak DJ, Moore JS. Columnar liquid crystals from shape persistent dendritic molecules, Angew. Chem. Int. Ed. Engl. 1999; 36: 1636-1639.

22. Gardikis K, Hatziantoniou S, Viras K, Wagner M, Demetzos C. A DSC and raman spectroscopy study on the effect of PAMAM dendrimer on DPPC model lipid membranes, Intl. J. Pharm. 2006; 318: 118-123.

23. Victoria M, Guerra J, Aldrik H, Richard M. NMR Characterization of Fourth-Generation PAMAM dendrimers in the presence and absence of palladium dendrimer-encapsulated nanoparticles. J. Am. Chem. Soc. 2009; 131:341-350.

24. Karlos X, Simanek E. Conformational analysis of triazine dendrimers: Using NMR spectroscopy to probe the choreography of a dendrimer's dance. Macromol. 2008; 41: 4108-4114. 